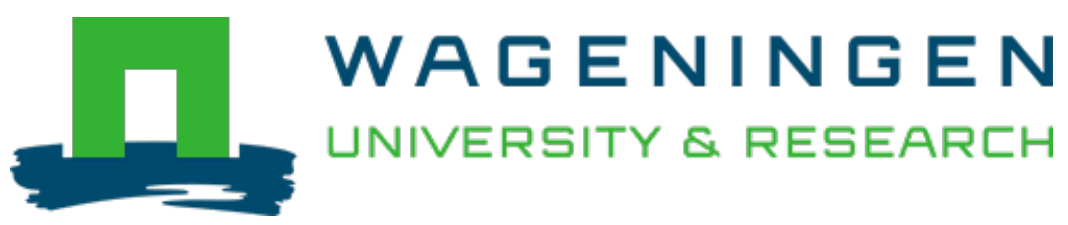

\title{
Generose: Genetic evaluation of European rose resources for conservation and horticultural use
}

\author{
Acta Horticulturae \\ Huylenbroeck, J.; Smulders, M.J.M.; Debener, T.; Nybom, H.; Gudin, S. et al \\ https://doi.org/10.17660/ActaHortic.2005.690.17
}

This article is made publicly available in the institutional repository of Wageningen University and Research, under the terms of article $25 \mathrm{fa}$ of the Dutch Copyright Act, also known as the Amendment Taverne. This has been done with explicit consent by the author.

Article 25 fa states that the author of a short scientific work funded either wholly or partially by Dutch public funds is entitled to make that work publicly available for no consideration following a reasonable period of time after the work was first published, provided that clear reference is made to the source of the first publication of the work.

This publication is distributed under The Association of Universities in the Netherlands (VSNU) 'Article $25 \mathrm{fa}$ implementation' project. In this project research outputs of researchers employed by Dutch Universities that comply with the legal requirements of Article $25 \mathrm{fa}$ of the Dutch Copyright Act are distributed online and free of cost or other barriers in institutional repositories. Research outputs are distributed six months after their first online publication in the original published version and with proper attribution to the source of the original publication.

You are permitted to download and use the publication for personal purposes. All rights remain with the author(s) and / or copyright owner(s) of this work. Any use of the publication or parts of it other than authorised under article $25 \mathrm{fa}$ of the Dutch Copyright act is prohibited. Wageningen University \& Research and the author(s) of this publication shall not be held responsible or liable for any damages resulting from your (re)use of this publication.

For questions regarding the public availability of this article please contact openscience.library@wur.nl 


\title{
GENEROSE: Genetic Evaluation of European Rose Resources for Conservation and Horticultural Use
}

Johan Van Huylenbroeck ${ }^{1}$, Marinus J.M. Smulders ${ }^{2}$, Thomas Debener ${ }^{3}$, Hilde Nybom ${ }^{4}$, Serge Gudin ${ }^{5}$, Peter $\mathrm{Cox}^{6}$, Laurent Crespel $^{7}$ and Jan De Riek ${ }^{1}$

${ }^{1}$ Department for Plant Genetics and Breeding, CLO-DVP, Caritasstraat 21, B-9090 Melle, Belgium

${ }^{2}$ Plant Research International, PO Box 16, NL-6700 AA Wageningen, The Netherlands

${ }^{3}$ Institute for Ornamental Plant Breeding, Bornkampsweg 31, D-22926 Ahrensburg, Germany

${ }^{4}$ Balsgård-Department of Crop Science, Swedish University of Agricultural Sciences, Fjälkestadsvägen 459, SE-291 94 Kristianstad, Sweden

${ }^{5}$ Laboratoire de Morphogenèse Végétale, Univ. de Droit, d'Economie et des Sciences (Aix-Marseille III), Avenue Escadrille Normandie-Niémen, F-13397 Marseille Cedex 20, France

${ }^{6}$ Horatia BV, Kaldenkerkerweg 197, NL-5930 AG Tegelen, The Netherlands

${ }^{7}$ Meilland International, Domaine Saint André, F-83350 Le Cannet-des-Maures, France

Keywords: biodiversity, breeding, disease resistance, germplasm, phylogeny, preservation, taxonomy, Rosa

\begin{abstract}
Under the adagio "Conservation by utilisation is the best way forward for a long-term sustainable protection of the remaining resources" the GENEROSEproject focuses on 3 major objectives: 1) sustainable conservation of wild resources by attributing them an extra value in landscaping or for disease resistance breeding; 2) development of efficient screening techniques for fungal disease resistance and 3) strategies to overcome crossing barriers between wild species and cultivated roses. The project integrates biotechnology (DNA markers for biodiversity evaluation and resistance mapping, flow cytometry for pollen sorting) with original breeding work (use of wild species) and direct potential end-use evaluation by rose breeders and growers. Apart from the ornamental value of possible new wild features, disease resistant cultivars will promote rose production with a lower environmental impact.
\end{abstract}

\section{INTRODUCTION}

Inventories of the occurrence and distribution of indigenous rose species have been performed in many European countries. These inventories are frequently limited to morphological and taxonomic descriptions although studies on inter- and intra-specific variability have been conducted in dogroses (Rosa sect. Caninae) using RAPDs (Olsson et al., 2000; Werlemark et al., 1999). In many other plant species, similar studies have been carried out on a large scale using also AFLP, DNA microsatellites and other related techniques. In roses, results are available on the use of these techniques for cultivar identification, for taxonomic studies in the genus Rosa and in the first genetic linkage maps (Debener and Mattiesch, 1999; De Riek et al., 2001; Zhang et al., 2000). Except for the studies on dogroses, most of the work in roses has up till now been conducted on cultivated material.

Cultivated roses have a very ancient history, and the first selections were reported already in the early $16^{\text {th }}$ century. Later on, artificial crossings led to what is today perceived as the 'modern rose cultivars'. However, the genetic basis on which these modern rose cultivars are established is very small. Several authors conclude that only between 8 and 20 species out of about 200 have contributed to the origin of our presentday rose cultivars (De Vries and Dubois, 1996; Gudin, 2001; Reynders-Aloisi and Bollereau, 1996). Many of the as yet unexploited rose species may contain valuable genes and traits of interest, which could be used for extending the present genetic diversity in breeding stock material. 
Unfortunately, interspecific hybridization has frequently been limited by crossing barriers, which are mainly caused by differences in ploidy level. A modern approach, incorporating techniques for pollen sorting and embryo rescue, should be able to overcome these problems. Pollen sorting has been used successfully in other plant species like Brassica napus (Deslauriers et al., 1991; Schulze and Pauls, 2001). Chromosome doubling in roses has mainly been attempted with colchicine, which has not been very successful. The effects of other, more recently applied chemicals like oryzalin still needs to be researched in roses. Recently, dihaploids (parthenogenetically derived by using irradiated pollen and in vitro embryo rescue from tetraploid modern cultivars) have been successfully crossed with diploid species. Interestingly, these dihaploids and their progenies (issued from crosses with wild diploid species) have been shown to produce often unreduced (2n) gametes in large quantities (Crespel et al., 2002).

Other techniques to increase genetic diversity in roses such as radiation, chemical mutagens, somaclonal variation and protoplast fusion have shown limited success (Gudin, 2001). Genetic transformation is an alternative approach to improve specific traits in roses. Some initial results have already been reported, but so far they do not concern agronomic traits (except one publication showing enhanced blackspot resistance) (Marchant et al., 1998). However, the strategy of our research project is to explore the existing diversity in the rose genus itself by developing new breeding strategies based on increased knowledge about the sexual physiology of this polyploid crop and on conventional genetic advances.

Current rose varieties are attacked by a large number of pathogens, under both field and greenhouse conditions. Among the most severe are the fungal diseases blackspot, powdery mildew, downy mildew and rust. Reports on resistance versus susceptibility of different rose varieties and species for all these diseases have been published over the last decades. However, only a few studies have employed systematic screening of the diversity of the pathogens and the respective host species (Debener et al., 1998; Yokoya et al., 2002). Defined genetic material in the form of single conidial isolates and characterized fungal races have only been reported for blackspot. Furthermore, following the genetic characterization of a resistance gene from $R$. multiflora, closely linked markers have been found and the molecular isolation of this gene by positional cloning is currently underway (von Malek et al., 2000). The first evidences for the occurrence of physiological races have also been reported for powdery mildew although detailed studies are still lacking (Bender and Coyier, 1984). Currently, analyses are being undertaken concerning the race structure for both powdery mildew and rust.

\section{PROJECT}

The GENEROSE-project started in 2003 within the European Research programme "Quality of Life and Management of Living Resources". Seven research groups and companies from Belgium, France, Germany, The Netherlands and Sweden participate in the consortium. The project consists of 4 major work programs which all focus on the conservation and use of natural resources in the genus Rosa.

\section{Genetic and Phylogenetic Relationships in Roses}

Attempts to preserve rose gene pools without sufficient knowledge about the genetic background may counter-act efforts to increase biodiversity, compromise the maintenance of (rare) indigenous species in landscaping and make it difficult to (re)introduce autochthonous plant material in the wild. Given that genetic authenticity is an important feature in nature conservancy, the use of molecular tools to perform an indepth investigation of genetic variability and relatedness is of utmost importance. Within the framework of the GENEROSE-project, a total 316 wild populations belonging to 28 different species have been sampled and described (Table 1). By the use of AFLP and microsatellite DNA markers, the genetic relationships between the different European species in the selected study areas and the biodiversity within and between populations of 
wild rose species is studied. Furthermore, a phylogenetic study is conducted, using material of the wild European species, cultivated roses and their supposed ancestors.

\section{Characterization of Fungal Diseases and Sources of Resistance}

In this project, the four main fungal diseases on roses (blackspot, powdery mildew, downy mildew and rust) are studied. The project aims to provide representative isolates of the different fungi to be used in standardized protocols for disease resistance screening. The collected wild rose species will be tested in order to point out which material can be useful for resistance breeding. Finally, genetic markers linked with disease resistance will be identified.

\section{Crossing Strategies for Interspecific Hybridizations}

A bottleneck in interspecific crosses with rose species at different ploidy levels is caused by the fact that the progeny has an uneven chromosome number (mostly triploids). Within the GENEROSE-project, different strategies to overcome these barriers are investigated, such as pollen sorting, polyploidization and dihaploidisation. Also the occurrence of unreduced gametes in roses is studied. Finally, gene transfer by diploid pollen derived from triploid plants is studied: DNA profiles are developed from haploid and diploid pollen, and compared to the profiles of the parent plants.

\section{Evaluation for Horticultural Use of Wild Rose Species}

Collected wild material is multiplied and evaluated for its potential use for landscaping and for horticulturally valuable traits like disease resistance, hip production, perfume, winter hardiness etc. Multiplication methods and cultivation techniques are tested in order to produce valuable plant material of autochthonous species.

\section{ACKNOWLEDGEMENTS}

This study has been carried out with financial support from the Commission of the European Communities, specific Research programme "Quality of Life and Management of Living Resources", QLRT-2001-01278 "Genetic evaluation of European rose resources for conservation and horticultural use". It does not necessarily reflect its views and in no way anticipates the Commission's future policy in this area.

\section{Literature Cited}

Bender, C.L. and Coyier, D.L. 1984. Isolation and identification of races of Sphaerotheca pannosa var. rosae. Phytopath. 73:100-103.

Crespel, L., Gudin, S., Meynet, J. and Zhang, D. 2002. AFLP-based estimation of 2n gametophytic heterozygosity in two parthenogenetically derived dihaploids of Rosa hybrida L. Theor. Appl. Genet. 104:451-456.

Debener, T., Drewes-Alvarez, R. and Rockstroh, K. 1998. Identification of five physiological races of black spot, Diplocarpon rosae Wolf. on roses. Plant Breed. 117:267-270.

Debener, T. and Mattiesch, L. 1999. Construction of a genetic linkage map for roses using RAPD and AFLP markers. Theor. Appl. Genet. 99:891-899.

De Riek, J., Dendauw, J., Leus, L., De Loose, M. and Van Bockstaele, E. 2001. Variety protection by use of molecular markers: some case studies on ornamentals. Plant Biosystems 135:107-113.

Deslauriers, C., Powell, A.D., Fuchs, K. and Pauls, K.P. 1991. Flow cytometric characterization and sorting of cultured Brassica napus microspores. Biochim. Biophys. Acta 1091:165-172.

De Vries, D.P. and Dubois, L. 1996. Rose breeding: past, present, prospects. Acta Hort. 424:241-248.

Gudin, S. 2001. Rose breeding technologies. Acta Hort. 547:23-26.

Marchant, R., Dazey, M.R., Lucas, J.A., Lamb, C.J., Dixson, R.A. and Power, J.B. 1998. Expression of kitinase transgen in rose (Rosa hybrida L.) reduces development of 
blackspot disease (Diplocarpon rosae Wolf). Mol. Breeding 4:187-194.

Olsson, A., Nybom, H. and Prentice, H.C. 2000. Relationships between Nordic dogroses (Rosa L. sect. Caninae, Rosaceae) assessed by RAPDs and elliptic Fourier analysis of leaflet shape. Syst. Bot. 25:511-521.

Reynders-Aloisi, S. and Bollereau, P. 1996. Characterisation of genetic diversity in genus Rosa by RAPD. Acta Hort. 424:253-259.

Schulze, D. and Pauls, P. 1998. Flow cytometric characterisation of embryogenic and gametophytic development in Brassica napus microspore cultures. Plant Cell Physiol. 39:226-234.

Von Malek, B., Weber, W.E. and Debener, T. 2000. Identification of molecular markers linked to $R d r 1$, a gene conferring resistance to blackspot in roses. Theor. Appl. Genet. 101:977-983.

Werlemark, G., Uggla, M. and Nybom, H. 1999. Morphological and RAPD markers show a highly skewed distribution in a pair of reciprocal crosses between hemisexual dogrose species, Rosa sect. Caninae. Theor. Appl. Genet. 98:557-563.

Yokoya, K., Kandasamy, K.I., Walker, S., Mandegaran, Z. and Roberts, A.V. 2000. Resistance of roses to pathotypes of Diplocarpon rosae Wolf. Ann. Appl. Biol. 136:15-20.

Zhang, D., Germain, E., Reynders-Aloisi, S. and Gandelin, M.H. 2002. Development of AFLP markers for variety identification in rose. Acta Hort. 502:113-120. 


\section{$\underline{\text { Tables }}$}

Table 1. Overview of the number of collected wild rose populations per country.

\begin{tabular}{|c|c|c|c|c|c|}
\hline Rose species & $\mathrm{B}^{*}$ & $\mathrm{D}$ & $\mathrm{F}$ & NL & Sca \\
\hline \multicolumn{6}{|l|}{ NON-DOGROSES } \\
\hline R. arvensis (incl. $R$. sempervirens) & 3 & 6 & 5 & 3 & \\
\hline R. majalis & & 5 & & & 2 \\
\hline R. pendulina $(R$. alpina $)$ & & 2 & 2 & & \\
\hline R. spinosissima ( $R$. pimpinellifolia) & 2 & 4 & 6 & 4 & \\
\hline \multicolumn{6}{|l|}{ INTERMEDIATE GROUP } \\
\hline $\begin{array}{l}\text { R. glauca Pourr. (R. rubrifolia) } \\
\text { (Sect. Cinnamomeae or Caninae) }\end{array}$ & 1 & 2 & 4 & & \\
\hline R. jundzilli (dogrose $\mathrm{x}$ R. gallica hybrid) & & 2 & & & \\
\hline R. gallica & & 2 & 8 & & \\
\hline \multicolumn{6}{|l|}{ DOGROSES } \\
\hline \multicolumn{6}{|l|}{ Subsection Caninae } \\
\hline R. canina & 4 & 12 & 3 & 23 & 8 \\
\hline R. subcanina & 2 & 1 & & 5 & \\
\hline R. dumalis & 1 & 1 & 1 & 5 & 14 \\
\hline R. corymbifera ( $R$. dumetorum) & 2 & 10 & 4 & 16 & \\
\hline R. subcollina & & & & 5 & \\
\hline R. caesia $($ R. coriifolia $)$ & 1 & 1 & 1 & 1 & 2 \\
\hline R. montana & & & 3 & & \\
\hline R. stylosa & 3 & & & & \\
\hline R. canina var. andegavensis & 1 & 1 & & & \\
\hline
\end{tabular}

\section{Subsection Rubigineae}

R. micrantha

$2 \quad 2$

R. columnifera

R. rubiginosa (R. eglanteria)

R. agrestis

54

R. inodora

2

R. elliptica

2

4

$\begin{array}{rrr} & 8 & 2 \\ 4 & 11 & 11 \\ 4 & 3 & \end{array}$

$\begin{array}{lll}1 & 2 & 1\end{array}$

\section{Subsection Vestitae}
$R$. tomentosa
R. pseudoscabriuscula
R. sherardii
R. villosa

3

3

10

6

1
3
4

\section{Subsection Tomentellae}

R. tomentella 
